\title{
DESCRIPTION OF THE TRANSFORMATION OF CHEMICAL SPECIES USING A COMBINATION OF CHEMICAL KINETICS AND CHEMICAL EQUILIBRIUM
}

\section{JIŘí HVĚZDA}

Josef Božek Research Centre, Technická 4, 16607 Praha 6, E-mail: jiri.hvezda@fs.cvut.cz

Motor System s.r.o., Machkova 587, 50011 Hradec Králové, E-mail: hvezda@motorsystem.cz

\section{SHRNUTí}

Tato práce prezentuje nový př́stup k numerické simulaci chemické přeměny složek v průběhu hoření.

$\checkmark$ prípadech abnormálně rychlých chemických reakcí je kinetické schéma kombinováno se schématem rovnovážným. Tímto způsobem jsou řešeny vážné výpočetní problémy jako je strnulost soustavy rovnic na straně jedné či numerická nestabilita na straně druhé.

Navržená procedura je ověěena na prípadu hoření vodíku popsaného reakčním mechanismem obsahujícím 23 paralelně probíhajících obecně vratných reakcí. Funkční sub-model chemické transformace bude implementován do více-zónového modelu spalování pro rešení chemických procesů ve frontě plamene a post-plamenných oblastech.

KLIIČOVÁ SLOVA: HOŘENII, CHEMICKÁ KINETIKA, CHEMICKÁ ROVNOVÁHA, VODÍK.

\section{ABSTRACT}

The paper presents a new approach for numerical simulation of the transformation of chemical species during combustion.

A standard kinetic arrangement is combined with an equilibrium one in the case of abnormally fast chemical reactions. In this way serious computational issues, such as equation system stiffness on one hand or numerical instability on the other, are resolved.

The proposed procedure is verified for the case of hydrogen combustion, described by a reaction mechanism consisting of 23 reactions running in parallel and generally reversible. A functional chemical transformation sub-model is implemented into the multi-zone model of combustion to treat the chemical processes in the flame and post-combustion areas.

KEYWORDS: COMBUSTION, CHEMICAL KINETICS, CHEMICAL EQUILIBRIUM, HYDROGEN.

\section{INTRODUCTION}

Combustion itself mainly involves the chemical transformation of the fresh fuel-air mixture into the final products. This process takes the form of a combination of various chemical reactions with various reaction rates. Three groups of chemical reactions can be distinguished in terms of chemical kinetics:

- Reactions with too slow a reaction rate, which have a negligible effect on final chemical composition.

- Reactions with too high a reaction rate, which cause the formation of components remaining in the chemical equilibrium state.

- Reactions with a reaction rate controlling the chemical process, which can determine how the mixture composition changes over time.

The change over time of the molar concentration vector of chemical components $\{[S]\}$ caused by a chemical process can generally be determined by means of the following equation, in accordance with [1]:

$$
\frac{d\left\{{ }_{s}[S]\right\}}{d t}=\left\|_{s^{*} r} C_{M}\right\| \cdot \frac{d\left\{_{r}[S]\right\}_{C H}}{d t},
$$

where $s$ is the number of components, $r$ is the number of reactions, $\left\|_{s^{*} r} C_{M}\right\|$ is the matrix of stoichiometric coefficients of forward and backward reactions. Then, the following equation can be obtained from Equation (1) by applying the main laws of chemical kinetics:

$\frac{d\{[S]\}}{d t}=\sum_{r}\left\{{ }_{s} C_{r}\right\} \cdot k_{r} \cdot \prod_{s}[S]^{x_{s, r}}$ 
Molar concentration changes of particular components $s$ can then be described by means of the matrix of stoichiometric coefficients and reaction rate constants $\left\|C_{s, r} k_{r}\right\|$ with $s$ rows, relevant to chemical components, and with $r$ columns, relevant to products of reagent molar concentrations powered by general exponents $x$.

A serious problem arises in the case of the above-mentioned fast chemical reactions leading to chemical equilibrium establishment. The right-hand side of Equation (2) may reach high values, which can lead to negative concentrations of given reactants, or instability of the numerical method. On the other hand, it is not possible to use an extremely short numerical step to suppress this effect. The considered differential equation system then generates very small derivatives, and problems with numerical precision during integration as system stiffness can occur.

Equation (2) can even be modified to the following form, if equilibrium state is established and there is no rapid temperature change:

$\frac{d\{[S]\}_{E}}{d t}=0=\sum_{r} C_{E, r} \cdot k_{r} \cdot \prod_{s}[S]^{x_{s, r}}$

So, each component in equilibrium state brings one non-linear algebraic binding Equation (3) among the unknowns. This equation enables the expression of an unknown concentration of the considered component by means of concentrations of other components and a matrix of known products $\left\|C_{s, r} k_{r}\right\|$.

The original purely kinetic scheme consisting of differential Equations (2), is thus being converted to an algebraic-differential system in the case of chemical equilibrium consideration. This system has to be solved generally in an iterative way, which can be highly complex. A general solution probably doesn't exist, and it is not easy to find an algorithm for more complicated systems that would implement equilibrium concentrations into differential equations of slow chemical reactions.

The main aim of this work is thus investigation of an alternative method of chemical equilibrium simulation in a form suitable for connection with the models of chemical kinetics.

\section{CHEMICAL KINETICS}

Consider a standard chemical kinetic arrangement, described by means of [2], composed from I simultaneously proceeding chemical reactions. An elementary reversible reaction involving $K$ chemical species can be represented in the general form:
$\sum_{k=1}^{K} v_{k i}^{\prime} X_{k} \leftrightarrow \sum_{k=1}^{K} v_{k i}^{\prime \prime} X_{k} \quad i=1,2, \ldots, \mathrm{I}$

where the stoichiometric coefficients $v_{k i}$ are integer numbers and $X_{k}$ is the chemical symbol for the $k$ th species. The superscript ' indicates forward stoichiometric coefficients, while " indicates reverse stoichiometric coefficients.

The production rate $\dot{\omega}_{k}$ of the $k$ th species can be written as a summation of the rate-of-progress variables for all reactions involving the $k$ th species:

$\dot{\omega}_{k}=\sum_{i=1}^{I} v_{k i} \cdot q_{i} \quad k=1,2, \ldots, \mathrm{K}$,

where

$v_{k i}=v_{k i}^{\prime \prime}-v_{k i}^{\prime}$

The rate of progress variable $q_{i}$ for the $i$ th reaction is given by the difference of the forward and reverse rates as:

$q_{i}=k_{f_{i}} \cdot \prod_{k=1}^{K}\left[X_{k}\right]^{v_{k i}^{k}}-k_{r_{i}} \cdot \prod_{k=1}^{K}\left[X_{k}\right]^{v_{k i}^{k i}}$

where $\left[X_{k}\right]$ is the molar concentration of the $k$ th species and $k_{f_{i}}$ and $k_{r_{i}}$ are the forward and reverse rate constants of the $i$ th reaction. Thus, the concentration of each reactant or product species is raised to the power of its stoichiometric coefficient.

The forward rate constant for the $i$ th reaction is generally assumed to have the following Arrhenius temperature dependence:

$k_{f_{i}}=A_{i} \cdot T^{b_{i}} \cdot \exp \left(\frac{-E_{i}}{R \cdot T}\right)$

where the pre-exponential factor $A_{i}$, the temperature exponent $\beta_{i^{\prime}}$ and the activation energy $E_{i}$ are specified.

In thermal systems, the reverse rate constants $k_{r_{i}}$ are related to the forward rate constants through the equilibrium constants by:

$k_{r_{i}}=\frac{k_{f_{i}}}{K_{c_{i}}}$ 
Although $K_{c_{i}}$ is given in concentration units, the equilibrium constants are more easily determined from the thermodynamic properties in pressure units. So, they are related by:

$K_{c_{i}}=K_{p_{i}} \cdot\left(\frac{p}{R \times T}\right)^{\sum_{k=1}^{K} v_{k i}}$.

The equilibrium constants $K_{p_{i}}$ are obtained with the relationship:

$K_{p_{i}}=\exp \left(\frac{\Delta S_{i}^{0}}{R}-\frac{\Delta H_{i}^{0}}{R \cdot T}\right)$.

The $\Delta$ refers to the changes of entropy and enthalpy, which occur in passing completely from reactants to products in the $i$ th reaction:

$\frac{\Delta S_{i}^{0}}{R}=\sum_{k=1}^{K} u_{k i} \cdot \frac{S_{k}^{0}}{R}$

$\frac{\Delta H_{i}^{0}}{R \cdot T}=\sum_{k=1}^{K} v_{k i} \cdot \frac{H_{k}^{0}}{R \cdot T}$

Moreover, a "third body" as a component designated $\mathrm{M}$ is required in some cases of dissociation or recombination reactions to enable them to proceed. Then the concentration of the effective third body and its efficiency $\alpha_{k_{i}}$ appear in the expression for the rate of progress variable. Accordingly, the first factor in Equation (14) modifies the original rate-of-progress variable defined by means of Equation (7):

$q_{i}=\left(\sum_{k=1}^{K}\left(\alpha_{k i}\right) \cdot\left[X_{k}\right]\right) \cdot\left(k_{f_{i}} \cdot \prod_{k=1}^{K}\left[X_{k}\right]^{v_{k i}^{\prime}}-k_{r_{i}} \cdot \prod_{k=1}^{K}\left[X_{k}\right]^{v_{k i}^{\prime \prime}}\right)$.

\section{CHEMICAL EQUILIBRIUM}

Instead of using algebraic equations for every reaction in equilibrium, the principle of minimum Gibbs free enthalpy was used for chemical equilibrium state description. Holub's method [3] applying the principles of the bounded extremes method, also known as the Lagrange multiplier method, can be used to find the molar fractions of species in the equilibrium condition.

In the following, an ideal gaseous system with $N$ chemical components with index $i=1,2, \ldots, \mathrm{N}$ and $M$ chemical elements with index $j=1,2, \ldots, \mathrm{M}$ is considered, where each element is represented by its amount $b_{j}$. Final function $F$ containing Lagrange multipliers $p_{j}$ to be minimized can be defined by means of Equations (15) to (18) and (19) using Gibbs free enthalpy $G^{0}$ corresponding to temperature $T$ :

$\Gamma(n)=\sum_{i=1}^{N} f_{i}, f_{i}=n_{i} \cdot\left[c_{i}+\ln \frac{n_{i}}{n}\right]$,

$c_{i}=\left(\frac{G^{0}}{R \cdot T}\right)_{i}+\ln p, \quad b_{j}=\sum_{i=1}^{N} a_{i j} \cdot n_{i}$

$F\left(n_{1}, \mathrm{n}_{2}, \ldots, \mathrm{n}_{N} ; \pi_{1}, \pi_{2}, \ldots, \pi_{\mathrm{M}}\right)=$

$=\Gamma\left(n_{1}, \mathrm{n}_{2}, \ldots, \mathrm{n}_{\mathrm{N}}\right)+\sum_{j=1}^{M} \pi_{j} \cdot\left(b_{j}-\sum_{i=1}^{N} a_{i j} \cdot n_{i}\right)$.

The input data for this method are initial molar quantities of considered chemical components $n_{i}$, pressure $p$ and temperature $T$. The output data are new molar quantities of considered chemical components $n_{i}$ corresponding to the state of chemical equilibrium at pressure $p$ and temperature $T$. In general, this result is obtained by solving the following equation system defined by Equations (20) and (21). The generalized Newtonian method is used for this calculation.

$\frac{\partial F}{\partial n_{i}}=0 \quad i=1,2, \ldots, \mathrm{N}$

$\frac{\partial F}{\partial \pi_{j}}=0 \quad j=1,2, \ldots, \mathrm{M}$

\section{COMBINATION OF BOTH APPROACHES}

Utilization of a purely kinetic scheme is quite problematic for more complex chemical systems created by a range of simultaneously running chemical reactions, where some of them have abnormally high values of reaction rates leading to chemical equilibrium state. Reasons and consequences of this fact were described in the introduction.

The main aim of this work is to present an alternative method for determination of chemical composition changes for more complicated chemical systems based on a combination of the kinetic approach and Holub's method for determination of chemical equilibrium. This algorithm, graphically shown in Figure 1, works in the following way: 
- Every time step of the numerical solution is initiated by a pure kinetic approach, and rate of progress variables $q_{i}$ for all reactions are calculated using Equation (14).

- Time derivatives of molar concentrations are determined by means of production rates $\omega_{k}$ calculated from Equation (5).

- The trial integration of molar concentrations is carried out and the possible presence of their negative values is checked.

- In the positive case, the reactions most responsible for negative molar concentrations are selected on the basis of values of rate of progress variables $q_{i}$. These selected reactions are excluded from the kinetic scheme (their rate of progress variables are set to 0 ).

- The kinetic part of the numerical step and reactions rejection process is repeated until there is no negative molar concentration after the trial integration.

- Chemical equilibrium state is calculated by means of the flexible Holub's method for reactants belonging to all excluded reactions.

- At the end of the numerical step, the chemical equilibrium state is calculated by means of the flexible Holub's method for reactants belonging to all excluded reactions, and new molar concentrations determined by means of the limited kinetic approach are completed by the equilibrium molar concentration vector.

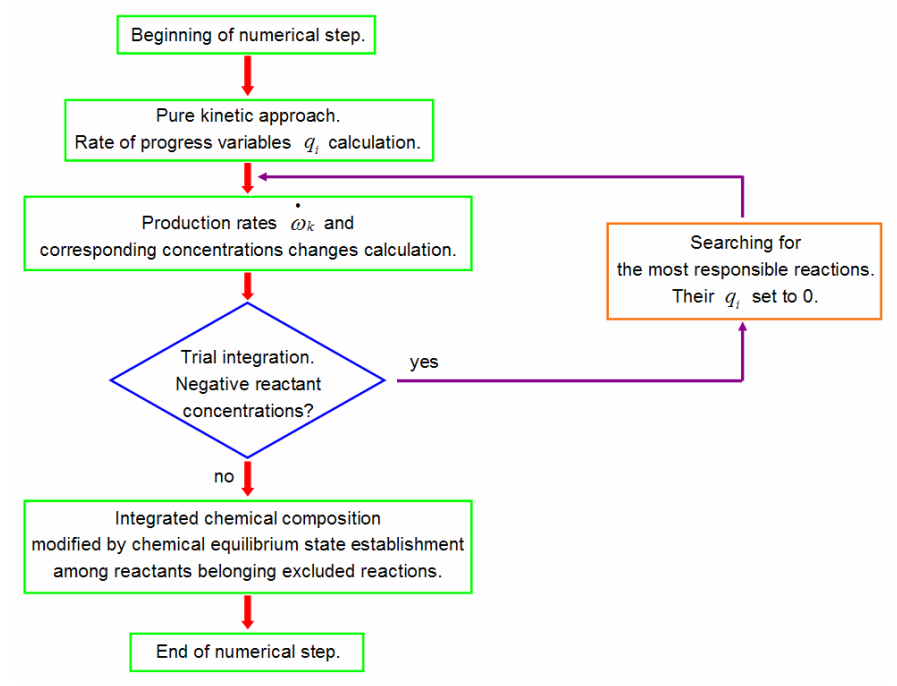

FIGURE 1: Numerical step flow chart.

OBRÁZEK 1: Vývojový diagram numerického kroku.

\section{RESULTS}

The functionality of the above procedure was checked for a relatively simple reaction mechanism belonging to hydrogen combustion. The complete mechanism of this chemical transformation consists of 23 reactions involving 11 species. For the following detailed reaction mechanism description, chemical kinetic and thermodynamic data required by Equations (8), (12) and (13) are obtained by means of [2]:

$\begin{array}{ll}01 & \mathrm{H}_{2}+\mathrm{O}_{2}=2 \mathrm{OH} \\ 02 & \mathrm{OH}+\mathrm{H}_{2}=\mathrm{H}_{2} \mathrm{O}+\mathrm{H} \\ 03 & \mathrm{O}+\mathrm{OH}=\mathrm{O}_{2}+\mathrm{H} \\ 04 & \mathrm{O}+\mathrm{H}_{2}=\mathrm{OH}+\mathrm{H} \\ 05 & \mathrm{H}+\mathrm{O}_{2}+\mathrm{M}=\mathrm{HO}_{2}+\mathrm{M} \\ 06 & \mathrm{OH}+\mathrm{HO}_{2}=\mathrm{H}_{2} \mathrm{O}+\mathrm{O}_{2} \\ 07 & \mathrm{H}+\mathrm{HO}_{2}=2 \mathrm{OH} \\ 08 & \mathrm{O}+\mathrm{HO}_{2}=\mathrm{O}_{2}+\mathrm{OH} \\ 09 & 2 \mathrm{OH}=\mathrm{O}+\mathrm{H} 2 \mathrm{O} \\ 10 & 2 \mathrm{H}+\mathrm{M}=\mathrm{H}_{2}+\mathrm{M} \\ 11 & 2 \mathrm{H}+\mathrm{H}_{2}=2 \mathrm{H}_{2} \\ 12 & 2 \mathrm{H}+\mathrm{H}_{2} \mathrm{O}=\mathrm{H}_{2}+\mathrm{H}_{2} \mathrm{O} \\ 13 & \mathrm{H}+\mathrm{OH}+\mathrm{M}=\mathrm{H}_{2} \mathrm{O}+\mathrm{M} \\ 14 & \mathrm{H}+\mathrm{O}+\mathrm{M}=\mathrm{OH}+\mathrm{M} \\ 15 & 2 \mathrm{O}+\mathrm{M}=\mathrm{O}_{2}+\mathrm{M} \\ 16 & \mathrm{H}+\mathrm{HO}_{2}=\mathrm{H}_{2}+\mathrm{O}_{2} \\ 17 & 2 \mathrm{HO}_{2}=\mathrm{H}_{2} \mathrm{O}_{2}+\mathrm{O}_{2} \\ 18 & \mathrm{H}_{2} \mathrm{O}_{2}+\mathrm{M}=2 \mathrm{OH}+\mathrm{M} \\ 19 & \mathrm{H}_{2} \mathrm{O}_{2}+\mathrm{H}=\mathrm{HO}+\mathrm{H}_{2} \\ 20 & \mathrm{H}_{2} \mathrm{O}_{2}+\mathrm{OH}=\mathrm{H}_{2} \mathrm{O}+\mathrm{HO}_{2} \\ 21 & \mathrm{O}+\mathrm{N}_{2}=\mathrm{NO}+\mathrm{N} \\ 22 & \mathrm{~N}+\mathrm{O}_{2}=\mathrm{NO}+\mathrm{O} \\ 23 & \mathrm{OH}+\mathrm{N}=\mathrm{NO}+\mathrm{H}\end{array}$

The proposed algorithm combining chemical kinetics and chemical equilibrium is processed numerically using the Fortran 77 programming language - [4] and [5], and the second order Runge-Kutta method is used. Selected results from the test example with the following features are presented.

- Stoichiometric combustion of hydrogen-air mixture.

- Initial temperature of $1000 \mathrm{~K}$ and pressure of $100 \mathrm{kPa}$.

- Combustion chamber volume of 1 liter.

Molar concentration trends for particular species during combustion are shown in Figure 2. Stoichiometric ratio of fuel-oxidizer mixture results in a very low amount of residual oxygen $\mathrm{O}_{2}$. The high temperature of the flame causes sizable content of dissociated gases, monatomic species $\mathrm{H}$ and $\mathrm{N}$ in the range of $10 \mathrm{E}-3$, monatomic 0 in the range of $10 \mathrm{E}-5$. The equilibrium amount of hydroxyl radical $\mathrm{OH}$ reaches the range of $10 \mathrm{E}-6$. Also, the activity of the Zeldovich mechanism, represented by the last three reactions of the reaction mechanism, is supported by high temperature resulting in a content of nitric oxide NO in the range of $10 \mathrm{E}-3$. 


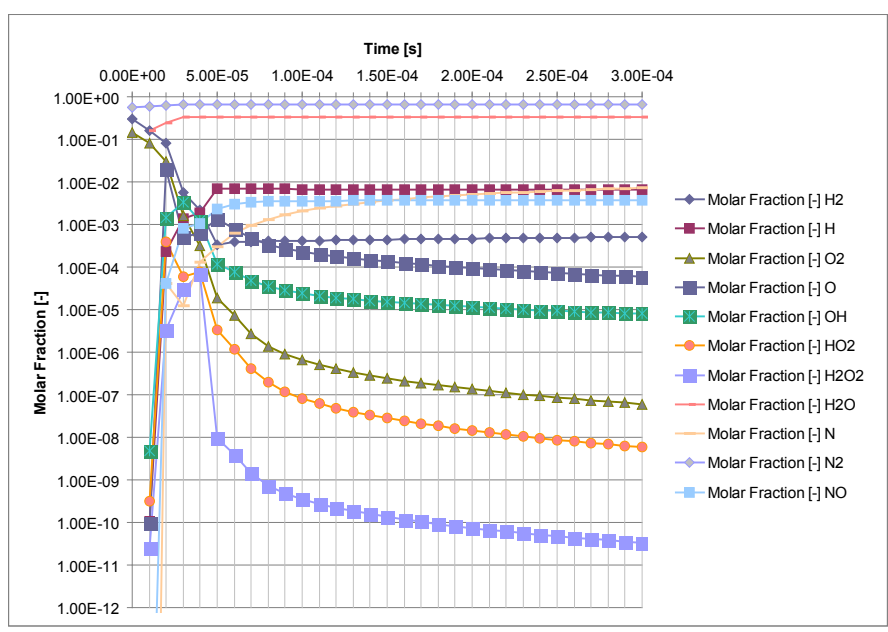

FIGURE 2: Molar fractions.

OBRÁZEK 2: Molární zlomky.

The corresponding pressure and temperature trends are shown in Figure 3. The presented data are calculated from energy conservation and state equations under conditions of isochoric adiabatic combustion. Here, a heat gain is determined from changes of absolute enthalpies corresponding to shortage or formation of particular species.

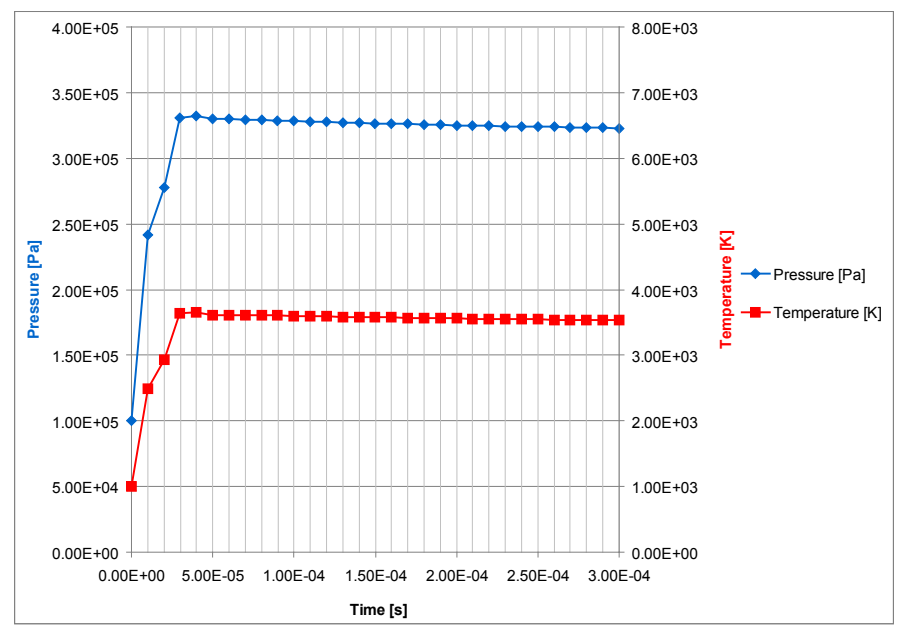

FIGURE 3: Pressure and temperature.

OBRÁZEK 3: Tlak a teplota.

The reactions and corresponding reactant species excluded from the kinetic scheme during the calculation are given the value 1 in Figure 4. Two lines for every point of numerical solution correspond to the first and second step of the second order Runge-Kutta method. Using the simplified method, three groups of chemical reactions can be distinguished. At first, reactions are proceeding slowly, which are never excluded from the kinetic scheme. Secondly, abnormally fast reactions responsible for negative reactant concentrations and are excluded almost always. In between, there are reactions whose rejection varies according to a two-step numerical method.

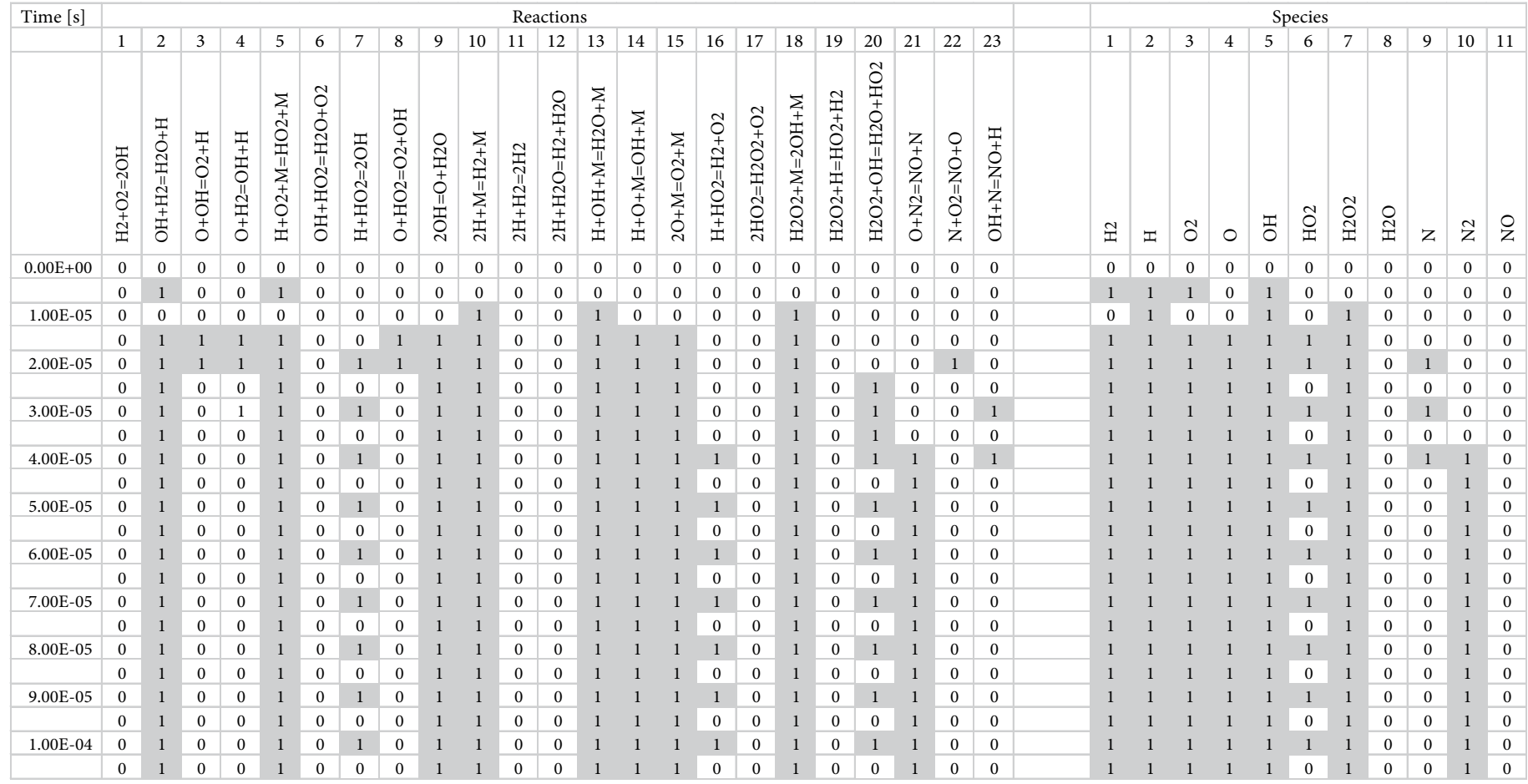

FIGURE 4: Excluded reactions and species.

OBRÁZEK 4: Vyloučené reakce a složky. 
Note, the presented results derive from the calculations where the third body effects defined by Equation (14) are neglected because of the lack of data concerning the efficiencies of certain species.

\section{CONCLUSION}

The results presented above demonstrate the ability of the new code to work.

The suggested procedure reliably detects negative concentrations of reactants past the trial integration and selects the responsible abnormally fast chemical reactions. Chemical equilibrium state is then established for reactants belonging these excluded reactions.

A standard chemical kinetic scheme is thus completed by means of the chemical equilibrium method. The numerical issues presented at the beginning of this paper are resolved in this way. Combustion process simulation displays good stability and very fast processing time of just a few seconds. Unfortunately, there are no available comparative data from other simulation codes at this moment; nevertheless, resultant molar fraction values presented in the previous chapter seem to be at the expected levels.

Following on from the above the author generally has two tasks for the near future. Firstly, to check the performance and behavior of the above-presented procedure for more complicated reaction mechanisms, especially methane or natural gas combustion. Secondly, the executed approach is going to be implemented into the multi-zone models of combustion and heat transfer processes in spark ignition engines [6], which are also being developed by the author. It will be used for treatment of chemical transformations in the flame front and post-combustion regions.

\section{ACKNOWLEDGMENT}

The results presented in the article have been obtained within the framework of participation of the author's workplace in the Integrated project InGas Integrated Gas Powertrain - Low Emission, $\mathrm{CO}_{2}$ optimized and efficient CNG engines for passengers cars (PC) and light duty vehicles (LDV) SCS7-GA-2008-218447.

\section{REFERENCES}

[1] Macek J. (2008). Současné Řešení Chemické Kinetiky a Rovnováhy. Faculty of Mechanical Engineering, Czech Technical University in Prague.

[2] Kee R. J., Rupley F. M., Miller J. A., Coltrin M. E., Grcar J. F., Meeks E., Moffat H. K., Lutz A. E., Dixon-Lewis G., Smooke M. D., Warnatz J., Evans G. H., Larson R. S., Mitchell R. E., Petzold L. R., Reynolds W. C., Caracotsios M., Stewart W. E., Glarborg P., Wang C. \& Adigun 0. (2000). CHEMKIN Collection, Release 3.6, Reaction Design, Inc., San Diego, CA.

[3] Holub R. (1972). Chemická Rovnováha Plynných Reakcí, Academia, Praha.

[4] Hřebíček J. a kolektiv (1989). Programovací Jazyk Fortran 77 a Vědeckotechnické Výpočty, Academia.

[5] Press W. H., Flannery B. P., Teukolsky S. A. \& Vetterling W. T. (1992). Numerical Recipes in Fortran 77. Cambridge University Press, Cambridge.

[6] Hvězda J. (2011). Multi-Zone Models of Combustion and Heat Transfer Processes in SI Engines, SAE Technical Paper 2011-37-0024, Torino. 